\title{
PENGARUH GAYA KOMUNIKASI GURU TERHADAP MOTIVASI BELAJAR SISWA
}

\author{
Vianesa Sucia \\ Program Studi Ilmu Komunikasi \\ Universitas Muhammadiyah Surakarta 2016 \\ Email : suciavianesa@gmail.com
}

\begin{abstract}
Many students' failures in perceiving the information from their teacher are caused by the unsuitability of communication style between teacher and students. It means that if a teacher has appropriate style in transferring information to the students, all subjects, including citizenship, will be easily understood. Indirectly, The fun style of teacher can improve the spirit or motivation of students in learning the materials given. Learning motivation of students can be arisen from the objective or encouragement to gain the expected results. This research aimed to study the effects of communication style of the teacher of Citizenship in motivating grade 8 students of Junior High Shool 3 of Wonogiri. The reseracher took 50 students of grade 8 in Junior High School 3 of Wonogiri as the samples of the research. The data analysis applied simple linear regression analysis. Data results showed that the communication style of teacher had significant influence in motivating learning motivation of grade 8 students of Junior High school 3 of Wonogiri so that it can be concluded that the style of communication of teacher took effect significantly in motivating learning motivation of students. However, data showed that there was only $28.2 \%$ of the learning motivation coming from the teacher's style of communication and the rest (71.8\%) came from other factors such as internal and external factors (society, family).
\end{abstract}

Keywords: The teacher's communication style, learning motivation of students, theory of subject-spesific motivation

\section{A. PENDAHULUAN}

Menurut Neacsu (Urea 2013) sekolah merupakan institusi dimana anak dapat mengembangkan bakat, kemampuan dan pengetahuan diberbagai bidang. Mereka mengembangkan kepribadian melalui aktivitas belajar. Dalam proses belajar terdapat dua hal yang penting, antara lain guru dan siswa dimana tiap-tiap dari mereka mempunyai sikap dan tujuan berbeda serta memiliki peran yang berbeda.

Guru merupakan sebuah profesi yang dipercaya untuk mendidik siswa, keberhasilan akan proses belajar mengajar digantungkan kepada guru, dan ketika terdapat suatu kesalahan dalam pendidikan seringkali gurulah yang menjadi sasaran. Dibalik semua itu terdapat beberapa faktor yang dapat mempengaruhi proses belajar siswa, antara lain: tingkat kecerdasan individu, perilaku guru, motivasi, dan tidak lupa pula minat belajar siswa, dari ke empat faktor tersebut guru dapat memberi motivasi yang dapat mendukung pendidikan. Seorang siswa dapat tertarik kemudian mendorongnya untuk dapat berkonsentrasi dalam belajar ataupun justru malah menarik diri dari kegiatan belajar mengajar dikarenakan takut atau cemas, hal tersebut salah akibat dari kesalahan guru dalam menerapkan perilakunya ( Al-Haddad, 2014). DePorter, Reardon \& Singer-Nourie (Susetyo) mengatakan bahwa kepercayaan seorang guru akan potensi individu dan kemampuan seorang siswa untuk belajar dan berprestasi merupakan suatu hal yang penting untuk diperhatikan.Utami (Putro, 2012) mengatakan bahwa guru adalah faktor yang penting dalam dunia pendidikan. Meski mempunyai fasilitas pendidikan yang 
lengkap dan canggih akan sia-sia apabila tidak ditunjang dengan guru yang berkualitas dan juga mustahil terciptanya kegiatan belajar mengajar yang maksimal.

Mengajar dan gaya belajar adalah perilaku atau tindakan yang guru dan peserta didik tunjukkan pada saat pembelajaran. Pengajaran perilaku mencerminkan keyakinan dan nilai-nilai guru dalam mentranser ilmu pengetahuan (Heimlich dan Norland, 2002). Perilaku peserta didik memberikan wawasan ke dalam cara memandang peserta didik, berinteraksi, dan merespon terhadap lingkungan di mana pembelajaran terjadi (Ladd dan Ruby, 1999). Dalam faktanya, banyak siswa mengalami kebingungan dalam menerima pelajaran karena tidak mampu mencerna materi yang diberikan oleh guru. Ternyata, banyaknya kegagalan siswa mencerna informasi dari gurunya disebabkan oleh ketidaksesuaian gaya komunikasinya. Sebaliknya, apabila gaya komunikasi guru sesuai dengan gaya belajar siswa, semua pelajaran akan terasa sangat mudah dan menyenangkan. Guru juga senang karena punya siswa yang semuanya cerdas dan berpotensi untuk sukses pada jenis kecerdasan yang dimilikinya. Tiga macam gaya komunikasi antara lain: non assertive ditandai dengan kecenderungan untuk menyembunyikan atau berdiam diri apabila terdapat suatu masalah. Hal tersebut mendorong individu untuk memilih berdiam diri dari pada memicu keramaian demi terciptanya perdamaian, assertive merupakan sebuah gaya yang ditandai dengan menyatakan opini secara langsung atau terbuka agar tujuan orang tersebut terpenuhi, agresive adalah gaya komunikasi yang ditandai dengan usaha individu untuk selalu hadir atau mendekatkan diri disetiap kesempatan(Urea, 2013).

Dengan adanya penerapan gaya komunikasi guru yang menyenangkan, secara tidak langsung hal ini dapat juga menumbuhkan semangat atau motivasi belajar siswa terhadap suatu mata pelajaran. Motivasi belajar yang timbul dalam diri siswa disebabkan karena adanya cita-cita atau dorongan untuk memperoleh hasil yang diharapkan.

Ryan \&Deci(Bailey dkk,2015)mengatakan bahwa motivasi merupakan suatu keinginan untuk mendapatkan suatu tantangan baru untuk menjelajah dan belajar. Dalam dekade ini, penelitian menyebutkan bahwa pengaruh dari konteks mengajar dalam tujuan orientasinya menyebutkan bahwa motivasi belajar berfokus pada peraturan dalam kelas, spesifiknya yaitu dalam tugas mengajar, penilaian, dan strategi pembelajaran. Didalam jurnal ini percaya bahwa tujuan orientasi merupakan faktor penting terhadap motivasi (Radovan dkk, 2015).

Boekaerts \& Simons (Brok, 2005) mengatakan bahwa ketika belajar mengenai motivasi, suatu penelitian seringkali membedakan antara sifat motivasi individu dan motivasi mata pelajaran khusus (subjectspecific motivation), kedua hal tersebut mempunyai pengertian yang berbeda. Sifat motivasi individu tercipta atau terbentuk karena diri individu itu sendiri, sedangkan motivasi mata pelajaran khusus tercipta atau terbentuk karena ada dorongan atau yang mempengaruhi dari luar. Meskipun kedua elemen diatas dapat berpengaruh pada pendidikan, akan tetapi pada penelitian ini akan fokus pada motivasi mata pelajaran khusus (subject-specific motivation) saja. Boekaerts \& Simons, 1995 dalam (Brok, dkk 2005) menyatakan bahwa Subject-specific motivation didalamstrukturorganisasiterdapat nilai, perilaku, dan konsep yang dimiliki siswa terhadap mata pelajaran khusus. Hasil struktur tersebut mengeneralisasikan atas perasaan, pikiran dan niat terhadap mata pelajaran tertentu di sekolah (Boekaerts \& Simons, 1995). Kesimpulan dari menggeneralisasi perasaan, pikiran dan niat terhadap subjek sekolah tertentu. Motivasi merupakan suatu yang sangat penting dibalik adanya prestasi. Motivasi siswa merupakan salah satu faktor yang penting dalam pembelajaran siswa (Haider dkk, 2015). Peneliti mempunyai perbedaan atas elemen dari motivasi mata pelajaran khusus, sebagian besar hanya mengambil empat elemen saja. Elemen tersebut antara lain: pleasure(kesenangan), relevance (hubungan), confidence (percaya 
diri), dan effort (upaya) Clement, Dornyei \& Noels, 1994; Gardner \& Maclntyre, 1993; Gardner \& Lambert, 1972; Khlemeier, van den Bergh \& Tenisse, 1990 (dalam Brok, dkk 2005).

Pleasure (kesenangan) mengandung arti bahwa siswa merasa senang atau gembira terhadap pengalaman siswa akan mata pelajaran, Relevance (hubungan)disini diartikan dengan hubungan antara guru dengan siswa atau tingkat kedekatan kedua belah pihak yang nantinya akan berpengaruh pada proses belajar mengajar, Confidence (percaya diri) yaitu siswa dapat mengikuti proses belajar mengajar dengan baik dan juga dapat memperoleh prestasi dimata pelajaran tertentu, sedangkan effort (upaya) diartikan dengan mereka (siswa) dapat mengeluarkan kemampuan yang mereka punya untuk mata pelajaran tertentu.Menurut Sardiman (dalam Yuliasari dkk, 2013) menyatakan bahwa motif merupakan suatu daya atau upaya yang dapat mendorong maupun menjadikan seseorang untuk melakukan suatu hal. Berawal dari kata motif diatas, maka dari itu motivasi dapat didefinisikan sebagai sebuah daya atau upaya sebagai penggerak yang telah menjadi aktif. Motif yang telah menjadi aktif pada waktu tertentu, terutama apabila ketika kebutuhan untuk mencapai tujuan sangat mendesak, pernyataan tersebut berarti motivasi akan aktif atau meningkat ketika individu ingin mewujudkan keinginan mereka.

Menurut Max Darsono (dalam Rusnandi, 2011) menyatakan bahwa motif merupakan sebuah upaya atau daya penggerak yang ada dalam diri individu untuk dapat melakukan kegiatan tertentu, jadi dapat dikatakan dari motif itu suatu kondisi internal artinya bahwa motif adalah kesiapsiagaan dalam diri individu itu sendiri. Sedangkan motivasi dapat diartikan sebagai motif yang telah menjadi aktif ketika melakukan suatu perbuatan, sedangkan motif tersebut telah ada didalam diri individu jauh sebelum orang itu melakukan suatu perbuatan. Motivasi membuat seseorang untuk dapat mengarahkan tindakan atau perilakunya serta memilih suatu tujuan belajar yang dirasakan dapatberguna bagi kehidupan individu. Motivasi mendorong individu untuk melakukan sesuatu, akan tetapi dari motivasi tersebut tidak dapat diamati ataupun dilihat secara langsung. Yang dapat dilihat secara langsung adalah sesuatu yang timbul dari motivasi itu dalam bentuk tingkah laku dan sikap.Individu dapat dikatakan berhasil dalam proses belajar mengajar apabila didalam diri individu itu sendiri terdapat keinginan untuk belajar, sebab tanpa individu itu mengerti apa yang akan dipelajari dan kurang memahami mengapa hal tersebut perlu dipelajari, maka proses belajar mengajar akan sulit untuk mencapai suatu keberhasilan. Keinginan atau dorongan yang dimiliki individu inilah yang disebut sebagai motivasi, dengan motivasi seseorang akan terdorong untuk melakukan sebuah pekerjaan guna mencapai sasaran dan tujuannya karena yakin dan sadar akan kebaikan, kepentingan maupun manfaatnya. Untuk seorang siswa motivasi ini dapat dikatakan sangatlah penting karena dengan motivasi tersebut dapat membuat perilaku siswa kearah yang positif sehingga mampu menghadapi suatu masalah.

Dalam penelitian ini peneliti akan mengambil sampel beberapa siswa yang ada di SMPN 3 WONOGIRI. Gaya komunikasi guru satu dan lainnya berbeda pula. Dari latar belakang diatas peneliti akan mengangkat masalah tersebut untuk bahan skripsi yang berjudul "Pengaruh Gaya Komunikasi Guru dan Motivasi Belajar Siswa (Studi Kuantitatif Eksplanatif Pengaruh Gaya Komunikasi Guru terhadap Motivasi Belajar Siswa Kelas VIII SMPN 3 Wonogiri)".

Berdasarkan uraian diatas, supaya permasalahan yang ada dapat dibahas secara runtun dan sesuai sasaran, maka dirumuskan permasalahan, yaitu: Apakah terdapat pengaruh gaya komunikasi guru terhadap motivasi belajar siswa kelas VIII SMPN 3 Wonogiri?

\section{B. TELAAH PUSTAKA}

\section{Gaya Komunikasi Guru}

Pendidikan adalah komunikasi dalam arti kata bahwa dalam proses tersebut terlibat dua komponen yang terdiri atas manusia, yakni pengajar sebagai komunikator dan pelajar sebagai komunikan. Lazimnya, pada tingkatan 
bawah dan menengah pengajar itu disebut guru, sedangkan pelajar itu disebut murid, pada tingkatan tinggi pengajar itu dinamakan dosen, sedangkan pelajar dinamakan mahasiswa. Pada tingkatan apa pun, proses komunikasi antara pengajar dan pelajar itu pada hakikatnya sama saja. Perbedaannya hanyalah pada jenis pesan serta kualitas yang disampaikan oleh si pengajar kepada si pelajar. Perbedaan antara komunikasi dengan pendidikan terletak pada tujuannya atau efek yang diharapkan. Ditinjau dari efek yang diharapkan itu, tujuan komunikasi sifatnya umum, sedangkan tujuan pendidikan sifatnya khusus. Kekhususan inilah yang dalam proses komunikasi melahirkan istilah-istilah khusus sepertipenerangan, propaganda, indoktrinasi, agitasi, dan pendidikan. Tujuan pendidikan adalah khas atau khusus, yakni meningkatkan pengetahuan seseorang mengenai suatu hal sehingga ia menguasainya.

Peran guru biasanya ditunjukkan melalui proses komunikasi yang dominan (didactic communications process). Didactic Communications merupakan proses yang melibatkan guru dan siswa. Didalam prosesnya seorang guru mendemonstrasikan gaya komunikasi secara spesifik dan sanggup menentukan kemampuannya dalam konteks komunikasi. Gaya komunikasi terdiri dari karakteristik individual yang berdampak pada cara komunikasi dan hal tersebut mengacu pada cara khusus dalam menerima pesan, kualitas personal dalam menginterpretasi pesan, carayang spesifikuntukmenyampaikan respon, sifat personal yang khusus dalam menyampaikan feedback (Urea, 2013).

Proses komunikasi dikatakan dapat berlangsung di dalam kelas. Penelitian terdahulu telah menyimpulkan bahwa suasana kelas harus memiliki kondisi yang aman, sesuai dan memadai bagi perkembangan murid. Dalam lingkungan yang nyaman tiap siswa akan dapat mengembangkan potensi yang dimiliki (Urea, 2013).

Menurut Urea, 2013 menyatakan bahwa terdapat tiga macam gaya komunikasi antara lain: non assertive ditandai dengan kecenderungan untuk menyembunyikan atau berdiam diri apabila terdapat suatu masalah. Hal tersebut mendorong individu untuk memilih berdiam diri dari pada memicu keramaian demi terciptanya perdamaian, assertive merupakan sebuah gaya yang ditandai dengan menyatakan opini secara langsung atau terbuka agar tujuan orang tersebut terpenuhi, agresive adalah gaya komunikasi yang ditandai dengan usaha individu untuk selalu hadir atau mendekatkan diri disetiap kesempatan.

Pendidikan adalah komunikasi dalam arti kata bahwa dalam proses tersebut terlibat dua komponen yang terdiri atas manusia, yakni pengajar sebagai komunikator dan pelajar sebagai komunikan. Lazimnya, pada tingkatan bawah dan menengah pengajar itu disebut guru, sedangkan pelajar itu disebut murid, pada tingkatan tinggi pengajar itu dinamakan dosen, sedangkan pelajar dinamakan mahasiswa. Pada tingkatan apa pun, proses komunikasi antara pengajar dan pelajar itu pada hakikatnya sama saja. Perbedaannya hanyalah pada jenis pesan serta kualitas yang disampaikan oleh si pengajar kepada si pelajar. Perbedaan antara komunikasi dengan pendidikan terletak pada tujuannya atau efek yang diharapkan. Ditinjau dari efek yang diharapkan itu, tujuan komunikasi sifatnya umum, sedangkan tujuan pendidikan sifatnya khusus. Kekhususan itulah yang dalam proses komunikasi melahirkan istilah-istilah khusus seperti penerangan, propaganda, indoktrinasi, agitasi, dan pendidikan. Menurut Effendy (Rusnandi, 2011) menyebutkan bahwa tujuan pendidikan merupakan sesuatu yang spesifik atau khusus, yakni menjadikan individu untuk meningkatkanpengetahuan tentang suatu persoalan sehingga individu tersebut menguasainya. Tujuan pendidikan tersebut akan dapat tercapai apabila proses yang dilalukan berjalan komunikatif. Apabila sebaliknya (tidak komunikatif, maka tujuan pendidikan itu mustahil dapat tercapai.Dalam proses belajar mengajar tidak akan terlepas dengan interaksi. Agar tujuan belajar tercapai maka dalam interaksi tersebut harus didukung dengan komunikasi yang efektif.

\section{Teori Subject-Specific Motivation}

Van Amelsvoort (Goh \& Khine, 2002), menjelaskan bahwa efek gaya komunikasi 
guru dalam motivasi mata pelajaran khusus kepada siswa (subject-specific motivation) baik langsung maupun tidak langsung lewat. Menurut Boekaerts \& Simons (Brok, dkk 2005) mengatakan bahwa ketika belajar mengenai motivasi, suatu penelitian seringkali membedakan antara sifat motivasi individu dan motivasi mata pelajaran khusus ( subjectspecific motivation), kedua hal tersebut mempunyai pengertian yang berbeda. Sifat motivasi individu tercipta atau terbentuk karena diri individu itu sendiri, sedangkan motivasi mata pelajaran khusus tercipta atau terbentuk karena ada dorongan atau yang mempengaruhi dari luar. Meskipun kedua elemen diatas dapat berpengaruh pada pendidikan, akan tetapi pada penelitian ini akan fokus pada motivasi mata pelajaran khusus (subject-specific motivation) saja. Boekaerts \& Simonsdalam (Brok, dkk 2005) menyatakan bahwa Subject-specific motivation didalam struktur organisasi terdapat nilai, perilaku, dan konsep yang dimiliki siswa terhadap mata pelajaran khusus. Hasil struktur tersebut mengeneralisasikan atas perasaan, pikiran dan niat terhadap mata pelajaran tertentu di sekolah (Boekaerts \& Simons, 1995). Kesimpulan dari menggeneralisasi perasaan, pikiran dan niat terhadap subjek sekolah tertentu.Menurut Brekelmans (Brok, 2005) menyatakan bahwa penelitian lain menemukan hubungan positif antara keramahan dan pemahaman perilaku, kesenangan, keyakinan, percaya diri, yang berkaitan dengan sejumlah mata pelajaran, sedangkan hubungan negatifyang ditemukan dengan menegur, tidak puas, dan kekerasan

Dalam penelitian sebelumnya yang dilakukan oleh Perry den Brok, dkk (2005), dengan jurnal "The Effect of Interpersonal Behavior on Students' Subject-Specific Motivation". Dari penelitian tersebut mengatakan Attitute Scale Towards English (ASE) menggunakan SubjectSpecific Motivation untuk ukuran. ASE mengembangkan penelitian dari Dutch Central Institute of Testing (CITO) untuk mengukur Subject-Specific Motivation siswa. Penelitian tersebut menyatakan bahwa terdapat empat elemen motivasi, yaitu pleasure (kesenangan), relevance (hubungan), confidence (percaya diri), dan effort (upaya) Clement, Dornyei \& Noels, 1994; Gardner \& Maclntyre, 1993; Gardner \& Lambert, 1972; Khlemeier, van den Bergh \& Tenisse, 1990 (dalam Brok, dkk 2005).

Pleasure (kesenangan) mengandung arti bahwa siswa merasa senang atau gembira terhadap pengalaman siswa akan mata pelajaran, sehingga siswa merasa bahagia dalam mengikuti mata pelajaran. Relevance (hubungan) disini diartikan dengan hubungan antara guru dengan siswa atau tingkat kedekatan kedua belah pihak yang nantinya akan berpengaruh pada proses belajar mengajar. Brekelmans, dkk (Brok 2005) mengatakan bahwa ada beberapa alasan untuk memperhatikan perilaku antarpribadi guru. Pertama, perilaku tersebut adalah komponen utama di dalam kelas dan banyak guru yang berpengalaman di dalam kelas. Kedua, penelitian telah menunjukkan bahwa gaya komunikasi guru adalah hal yang terkait dengan prestasi siswa dan motivasi dalam semua subjek. Selalu menjalin hubungan (kedekatan) dengan siswa merupakan salah satu perilaku guru di dalam kelas yang dapat dihubungkan dengan motivasi belajar siswa. Confidence (percaya diri) yaitu siswa dapat mengikuti proses belajar mengajar dengan baik dan juga dapat memperoleh prestasi dimata pelajaran tertentu hal tersebut disebabkan oleh adanya rasa percaya diri seorang siswa, kedekatan seorang guru dengan siswa dapat berpengaruh pada tingkat kepercayaan diri siswa. Percaya diri berarti percaya akan kemampuan yang ada, mempunyai rasa kepercayaan dan kepastian. Menurut Sniezek (Wesson, 2005) salah satu pilihan dalam kepercayaan diri adalah berbicara mengenai masalah ketidakpastian dalam diri tentang kelebihan yang dimiliki dalam diri.Dengan kepercayaan diri kita dapat menentukan jalan yang akan kita ambil. Jika kita memiliki kepercayaan yang penuh, itu semua akan sangat berpengaruh pada pilihan yang kita ambil. Menurut Afiatin dan Budi Andayani (Santoso, 2015), menjelaskan bahwa kepercayaan diri merupakan satu aspek kepribadian yang terbentuk melelui interaksi individu dengan lingkungannya, sedangkan effort (upaya) diartikan dengan mereka (siswa) 
dapat mengeluarkan kemampuan yang mereka punya untuk mata pelajaran tertentu. Subject-Specific Motivation theory akan digunakan dalam penelitian ini. Teori mata pelajaran khusus (Subject-Specific Motivation theory) akan digunakan untuk mengkaji beberapa mata pelajaran yang diajarkan oleh guru di SMPN 3 WONOGIRI, dengan begitu peneliti dapat mengetahui motivasi yang dimiliki masing-masing siswa dari mata pelajaran tersebut, gaya komunikasi guru dan juga motivasi siswa terhadap mata pelajaran khusus di dalam sekolah tersebut dapat berpengaruh pada proses pembelajaran dan juga motivasi yang terbentuk.

Menurut Sardiman (Yuliasari dkk, 2013) menyatakan bahwa motif merupakan suatu daya atau upaya yang dapat mendorong maupun menjadikan seseorang untuk melakukan suatu hal. Berawal dari kata motif diatas, maka dari itu motivasi dapat didefinisikan sebagai sebuah daya atau upaya sebagai penggerak yang telah menjadi aktif. Motif yang telah menjadi aktif pada waktu tertentu, terutama apabila ketika kebutuhan untuk mencapai tujuan sangat mendesak. Menurut Max Darsono (Rusnandi, 2011) menyatakan bahwa motif merupakan sebuah upaya atau daya penggerak yang ada dalam diri individu untuk dapat melakukan kegiatan tertentu, jadi dapar dikatakan dari motif itu suatu kondisi internal artinya bahwa motif adalah kesiapsiagaan dalam diri individu itu sendiri. Sedangkan motivasi dapat diartikan sebagai motif yang telah menjadi aktif ketika melakukan suatu perbuatan, sedangkan motif tersebut telah ada didalam diri individu jauh sebelum orang itu melakukan suatu perbuatan.

\section{Kerangka Berfikir}

\begin{tabular}{|c|c|}
\hline Variabel Independen \\
\hline Gaya Komunikasi Guru \\
-Assertive \\
-Non Assertive \\
-Agresive
\end{tabular}$\longrightarrow$\begin{tabular}{cc|} 
Variabel Dependen \\
\\
Motivasi Belajar Siswa \\
-Pleasure \\
-Relevance \\
-Confidence \\
-Effort \\
\hline
\end{tabular}

\section{Hipotesis}

Ho: Tidak ada pengaruh gaya komunikasi guru terhadap motivasi belajar siswa.
Ha: Ada pengaruh gaya komunikasi guru terhadap motivasi belajar siswa.

\section{METODE PENELITIAN}

Metode penelitian merupakan cara peneliti menjelaskan pendekatan, metode, teknik yang digunakan dalam penelitian. Salah satu tujuan dari penelitian adalah untuk memecahkan masalah, dengan demikian langkah-langkah yang ditempuh harus relevan dengan masalah yang telah dirumuskan. Jenis penelitian yang digunakan oleh penulis adalah penelitian kuantitatif yang merupakan penelitian dimana data yaitu berupa angka yang kemudian hasilnya dapat digeneralisasikan (Kriyantono, 2010). Dalam penelitian ini menggunakan dua variabel yaitu variabel independen $(\mathrm{x})$, gaya komunikasi guru serta variabel dependen $(Y)$, motivasi siswa. Beberapa indikator digunakan untuk alat ukur. Gaya komunikasi diukur dari gaya assertive, non-assertive, aggresive, serta motivasi belajar diukur dari pleasure, relevance, confidence, dan effort.

Penelitian ini menggunakan dua sumber, yaitu sumber primer dan sekunder. Sumber primer didapat dari penyebaran kuesioner, sedangkan sumber sekunder didapat dari buku, jurnal, dan juga internet. Kuesioner dalam penelitian ini bersifat tertutup, dimana responden diberikan beberapa alternatif jawaban. Alternatif jawaban berupa pernyataan Sangat Setuju (SS), Setuju (S), Tidak Setuju (TS), Sangat Tidak Setuju (STS).Ketika menyebar kuesioner peneliti menjauhkan diri dari objek agar data yang didapat bersifat netral.Objek dalam penelitian ini berlokasi di SMPN 3 Wonogiri atau yang sering disebut Spenga. Sekolah ini berlokasi di Jalan Ki Mangun Sarkoro 59 Wonogiri.Penelitian ini dimulai pada bulan Mei 2016 di SMPN 3 Wonogiri. Dalam penelitian ini menggunakan 50 siswa kelas VIIIG dan VIIIF SMP N 3 Wonogiri sebagai sampel penelitian. Sampel dipilih karena memenuhi kriteria penelitian, kriteria tersebut antara lain: dipilih kelas yang mempunyai nilai rata-rata yang tinggi, dan diajar oleh guru yang sama (PPKN). Teknik pengambilan sampel menggunakan sampel 
jenuh karena melihat jumlah populasi yang relatif kecil (Sugiyono, 2012). Jenis riset yang dipilih yaitu jenis eksplanatif dimana peneliti mencari sebab akibat antara dua variabel. Analisis data dalam penelitian ini dilakukan untuk mengetahui pengaruh gaya komunikasi guru terhadap motivasi siswa kelas VIII SMPN 3 Wonogiri. Analisis data dalam penelitian ini dilakukan dengan menggunakan alat analisis regresi linier sederhana. Analisis regresi linier sederhana digunakan untuk meneliti apakah ada pengaruh yang signifikan diantara sebab akibat tersebut. Analisis ini dipakai apabila dalam penelitian terdapat data dari dua variabel yang terdiri dari variabel bebas $X$ dan variabel terikat $Y$. Pengolahan data menggunakan SPSS 17.0.

Nilai-nilai $Y$ dapat dihitung berdasarkan nilai $X$ tertentu. Adapun rumus yang digunakan:

$$
Y=a+b X
$$

Di mana:

$\mathrm{Y}=$ variabel tidak bebas (subjek dalam variabel yang tak bebas/dependen yang diprediksi)

$\mathrm{X}=$ variabel bebas (subjek pada variabel independen yang mempunyai nilai tertentu)

$a=$ nilai intercept (konstan) atau harga $Y$ bila $X=0$

$\mathrm{b}=$ koefisien regresi, yaitu angka peningkatan atau penurunan variabel dependen yang padavariabel independen. Bila (+) maka naik, bila (-) maka terjadi penurunan.

Nilai a dihitung dengan rumus:

$$
\mathrm{a}=\frac{\sum Y\left(\sum X^{2}\right)-\sum X \sum X Y}{n \sum X^{2}-(X)^{2}}
$$

Nilai b dihitung dengan rumus:

$$
\mathrm{b}=\frac{n 2 X Y-2 X 2 X Y}{n \sum X^{2}-(X)^{2}}
$$

(Kriyantono, 2006)

Selanjutnya dalam analisis regresi linier sederhana ada uji $t$, uji $F$ dan koefisien determinasi $\left(R^{2}\right)$ sebagai kelengkapan pengujian.

\section{Uji t}

Uji $t$ digunakan untuk pengujian signifikansi koefisien regresi, yakni signifikansi dari pengaruh gaya komunikasi guru terhadap motivasi belajar siswa. Langkah-langkah pengujian sebagai berikut:

1. Menentukan $\mathrm{H}_{0}$ dan $\mathrm{H}_{1}$ $\mathrm{H}_{0}: \mathrm{b}_{1}=0$; tidak terdapat pengaruh gaya komunikasi guru(X) terhadap motivasi belajar siswa(Y).

$\mathrm{H}_{1}: \mathrm{b}_{1} \neq 0$; terdapat pengaruh gaya komunikasi guru(X) terhadap motivasi belajar siswa $(Y)$.

2. Menentukan level of significant $\alpha=5 \%$

3. Menghitung nilai t

$\mathrm{t}_{\text {hitung }}=\frac{b}{S_{b}}$

Di mana:

$\mathrm{b}=$ koefisien regresi

$\mathrm{S}_{\mathrm{b}}=$ Standar eror koefisien regresi

(Sanusi, 2012)

4. Kriteria pengujian

$H_{0}$ diterima jika $-t_{\text {tabel }} \leq t_{\text {hitung }} \leq t_{\text {tabel }}$ atau nilai signifikansi $>0,05$

$\mathrm{H}_{0}$ ditolak jika $\mathrm{t}_{\text {hitung }}<-\mathrm{t}_{\text {tabel }}$ atau $\mathrm{t}_{\text {hitung }}>\mathrm{t}_{\text {tabel }}$ atau nilai signifikansi $<0,05$

5. Kesimpulan

Untuk mengetahui diterima atau ditolaknya $\mathrm{H}_{0^{\prime}}$ maka hasil perhitungan signifikansi dibandingkan dengan level of significant $=0,05$. Apabila nilai signifikansi $<0,05$ maka hipotesis nol $\left(\mathrm{H}_{0}\right)$ ditolak, hal ini menunjukkan ada pengaruh yang signifikan antara variabel $X$ terhadap variabel Y. Sedangkan jika nilai signifikansi $>0,05$ maka $\mathrm{H}_{0}$ diterima, hal ini menunjukkan tidak ada pengaruh yang signifikan antara variabel $X$ terhadap variabel Y.

\section{Uji F}

Uji $F$ digunakan untuk mengetahui signifikansi pengaruh variabel independen secara bersama-sama terhadap variabel dependen. Langkah-langkah pengujian sebagai berikut: 
1. Menentukan $\mathrm{H}_{0}$ dan $\mathrm{H}_{1}$ $\mathrm{H}_{0}: \mathrm{b}_{1}=\mathrm{b}_{2}=0$; tidak terdapat pengaruh secara bersama-sama gaya komunikasi guru(X) terhadap motivasi belajar $\operatorname{siswa}(\mathrm{Y})$.

$\mathrm{H}_{1}: \mathrm{b}_{1}=\mathrm{b}_{2} \neq 0$; terdapat pengaruh secara bersama-sama gaya komunikasi guru(X) terhadap motivasi belajar siswa(Y).

2. Menentukan level of significant $\alpha=5 \%$

3. Menghitung nilai $\mathrm{F}$

$$
\mathrm{F}_{\text {hitung }}=\frac{S S R / k}{S S E /[n-(k+1)]}
$$

Di mana,

$\mathrm{SSR}=$ keragaman regresi (SS Total $-\mathrm{SSE})$

SSE $=$ keragaman kesalahan

$\mathrm{n}=$ jumlah variabel bebas

$\mathrm{k}=$ jumlah sampel

(Sanusi, 2012)

4. Kriteria pengujian

$\mathrm{H}_{0}$ diterima jika $\mathrm{F}_{\text {hitung }}<\mathrm{F}_{\text {tabel }}$ atau nilai signifikansi $>0,05$

$\mathrm{H}_{0}$ ditolak jika $\mathrm{F}_{\text {hitung }}>\mathrm{F}_{\text {tabel }}$ atau nilai signifikansi $<0,05$

5. Kesimpulan

Untuk mengetahui diterima atau ditolaknya $\mathrm{H}_{0^{\prime}}$ maka hasil perhitungan signifikansi dibandingkan dengan level of significant $=0,05$. Apabila nilai signifikansi $<0,05$ maka hipotesis nol $\left(\mathrm{H}_{0}\right)$ ditolak, hal ini menunjukkan bahwa variabel $X$ secara bersama-sama mempengaruhi variabel Y secara signifikan. Sedangkan jika nilai signifikansi > 0,05 maka $\mathrm{H}_{0}$ diterima, hal ini menunjukkan bahwa variabel $\mathrm{X}$ secara bersama-sama tidak mempengaruhi variabel Y secara signifikan.

\section{Uji Koefisien Determinasi $\left(R^{2}\right)$}

Pengujian koefisien determinasi $\left(R^{2}\right)$ digunakan untuk mengetahui sumbangan yang diberikan variabel bebas terhadap variabel terikat yang ditunjukkan dalam prosentase. Adapun rumus yang digunakan adalah sebagai berikut:

$$
\mathrm{R}^{2}=\frac{S S R}{S S T} \text { atau } R_{\text {adjusted }}^{2}=1-\left(1-\mathrm{R}^{2}\right) \frac{n-1}{n-k}
$$

Di mana,

$\mathrm{SSR}=$ keragaman regresi (SS Total $-\mathrm{SSE})$

SST $=$ keragaman total

$\mathrm{n}$ = jumlah sampel

k = jumlah variabel bebas (Sanusi, 2012)

\section{HASILPENELITIANDAN PEMBAHASAN}

\section{Pengujian Persyaratan Analisis}

\section{Uji Validitas}

Hasil kuesioner yang telah didapat, diuji validitasnya dengan menggunakan aplikasi SPSS for windows. Item-item pernyataan berkorelasi signifikan dengan skor total menunjukkan bahwa item pernyataan tersebut valid. Pada penelitian ini menggunakan 50 responden sehingga dapat diketahui bahwa $r$ tabelnya adalah 0.279. Nilai dari $r$ hitung harus lebih besar daripada $r$ tabel sehingga dapat dikatakan 'valid'.

Pada penelitian ini pengujian validitas dilakukan pada variabel gaya komunikasi guru (X) dan motivasi belajar siswa (Y). Gaya komunikasi guru terdiri dari tiga aspek, yaitu gaya komunikasi assertive, gaya komunikasi agresive dan gaya komunikasi non assertive. Hasil pengujian validitas pada gaya komunikasi asertive terdapat 4 item pernyataan yang setelah diuji validitas diperoleh hasil bahwa pada pernyataan pertama adalah 0.501; pada pernyataan kedua adalah 0.779; pada pernyataan ketiga adalah 0.768 dan pada pernyataan keempat adalah 0.762 . Keempat pernyataan menunjukkan nilai $r_{x y}$ lebih besar dari pada angka $r$ tabel yaitu 0.279 sehingga keempat pernyataan pada aspek gaya komunikasi assertive ini dinyatakan Valid.

Gaya komunikasi agresive juga terdapat 4 item pernyataan yang setelah diuji validitas diperoleh hasil bahwa pada pernyataan pertama adalah 0.701; pada pernyataan kedua adalah 0.649; pada pernyataan ketiga adalah 0.639 dan pada pernyataan keempat adalah 0.664. Keempat pernyataan menunjukkan nilai $r_{x y}$ lebih besar dari pada angka $r$ tabel yaitu $0.279^{x y}$ sehingga keempat pernyataan pada aspek gaya komunikasi agresive ini dinyatakan Valid. Adapun pada gaya komunikasi non 
assetive dari 4 item pernyataan pernyataan yang setelah diuji validitas diperoleh hasil bahwa pada pernyataan pertama adalah 0.460; pada pernyataan kedua adalah 0.704; pada pernyataan ketiga adalah 0.666 dan pada pernyataan keempat adalah 0.671. Keempat pernyataan menunjukkan nilai $r_{x y}$ lebih besar dari pada angka $r$ tabel yaitu 0.279 sehingga keempat pernyataan pada aspek gaya komunikasi pasif ini dinyatakan Valid

Berdasarkan hasil perhitungan di atas, dapat disimpulkan bahwa pada ketiga aspek di atas yaitu aspek gaya komunikasi assertive berisi 4 pernyataan, gaya komunikasi agresive berisi 4 pernyataan dan aspek gaya komunikasi non assertive yang digunakan berisi 4 pernyataan memiliki nilai lebih dari $r$ tabel yaitu 0.279 sehingga dinyatakan valid.

Hasil pengujian validitas pada variabel motivasi belajar siswa terdiri dari 4 aspek yaitu pleasure (kesenangan), relevance (hubungan), confidence (percaya diri), dan effort (upaya). Hasil pengujian validitas pada aspek pleasure (kesenangan) terdapat 3 item pernyataan yang setelah diuji validitas diperoleh hasil bahwa pada pernyataan pertama adalah 0.613; pada pernyataan kedua adalah 0.582 dan pada pernyataan ketiga adalah 0.610. Ketiga pernyataan menunjukkan nilai $r_{x y}$ lebih besar dari pada angka $r$ tabel yaitu 0.279 sehingga ketiga pernyataan pada aspek pleasure (kesenangan) ini dinyatakan Valid. Hasil pengujian validitas pada aspek relevance (hubungan) terdapat 3 item pernyataan yang setelah diuji validitas diperoleh hasil bahwa pada pernyataan pertama adalah 0.492; pada pernyataan kedua adalah 0.757 dan pada pernyataan ketiga adalah 0.595 . Ketiga pernyataan menunjukkan nilai $r_{x y}$ lebih besar dari pada angka $r$ tabel yaitu 0.279 sehingga ketiga pernyataan pada aspek relevance (hubungan) ini dinyatakan Valid.

Pengujian validitas pada motivasi belajar siswa aspek confidence (percaya diri) terdapat 4 item pernyataan yang setelah diuji validitas diperoleh hasil bahwa pada pernyataan pertama adalah 0.588; pada pernyataan kedua adalah 0.541 ; pada pernyataan ketiga adalah 0.636 dan pada pernyataan keempat adalah
0.500. Keempat pernyataan menunjukkan nilai $r_{x y}$ lebih besar dari pada angka $r$ tabel yaitu 0.279 sehingga keempat pernyataan pada aspek confidence (percaya diri) ini dinyatakan Valid. Hasil pengujian pada aspek effort (upaya) terdapat 4 item pernyataan yang setelah diuji validitas diperoleh hasil bahwa pada pernyataan pertama adalah 0.406 ; pada pernyataan kedua adalah $0.502 ;$ pada pernyataan ketiga adalah 0.462 dan pada pernyataan keempat adalah 0.576 . Keempat pernyataan menunjukkan nilai $r_{x y}$ lebih besar dari pada angka $r$ tabel yaitu 0.279 sehingga keempat pernyataan pada aspek confidence (percaya diri) ini dinyatakan Valid.

Berdasarkan hasil perhitungan di atas, dapat disimpulkan bahwa pada keempat aspek di atas yaitu aspek pleasure (kesenangan) berisi 3 pernyataan, relevance (hubungan) berisi 3 pernyataan, confidence (percaya diri) berisi 4 pernyataan, dan aspek effort (upaya) yang digunakan berisi 4 pernyataan memiliki nilai lebih dari $r$ tabel yaitu 0.279 sehingga dinyatakan valid.

\section{Uji Reliabilitas}

Berikut ini adalah hasil uji reliabilitas dari aspek Gaya Komunikasi dan Motivasi Belajar. Apabila digabungkan, kedua aspek tersebut memiliki 26 butir pernyataan yang setelah diuji mendapatkan hasil sebagai berikut:

Tabel 1. Uji reliabilitas data

\begin{tabular}{rr}
\multicolumn{2}{c}{ Reliability Statistics } \\
\hline $\begin{array}{c}\text { Cronbach's } \\
\text { Alpha }\end{array}$ & of Items \\
\hline .882 & 12 \\
.826 & 14 \\
\hline
\end{tabular}

Sumber: Hasil pengolahan data pada lampiran

Setelah peneliti melakukan uji reliabilitas, maka diketahui hasil Cronbach's Alpha dari hasil olah data pada variabel gaya komunikasi guru adalah 0.882 dan pada motivasi belajar siswa adalah 0.826 yang mana hasil tersebut lebih besar daripada 0.6. Dengan demikian maka dapat dikatakan bahwa alat ukur dalam penelitian ini Reliabel. 


\section{Analisis Data}

\section{Gaya Komunikasi Guru}

\begin{tabular}{llll}
\multicolumn{4}{c}{ Item Statistics } \\
\hline & Mean & Std. Deviation & $\mathrm{N}$ \\
\hline ITEM 1 & 2.92 & .778 & 50 \\
ITEM 2 & 3.02 & .769 & 50 \\
ITEM 3 & 2.86 & .808 & 50 \\
ITEM 4 & 3.10 & .789 & 50 \\
ITEM 5 & 2.90 & .789 & 50 \\
ITEM 6 & 3.36 & .749 & 50 \\
ITEM 7 & 3.02 & .622 & 50 \\
ITEM 8 & 2.98 & .685 & 50 \\
ITEM 9 & 2.92 & .900 & 50 \\
ITEM 10 & 3.06 & .740 & 50 \\
ITEM 11 & 3.12 & .799 & 50 \\
ITEM 12 & 3.30 & .763 & 50 \\
\hline
\end{tabular}

Sumber: Hasil pengolahan data pada lampiran

a. Aspek Assertive

Aspek assertive ditunjukkan oleh item 1 sampai dengan 4 yang menghasilkan jumlah skor sebanyak 595 dan memiliki nilai mean 2.975 yang merupakan nilai mean diantara keempat pernyataan yang diteliti. Nilai tersebut termasuk dalam kategori Baik sesuai dengan rating skor skala penilaian. Dari nilai di atas berarti guru menyampaikan materi pelajaran dengan secara tegassetiap pembelajaran dikelas, selalu masuk kelas, saat jam pelajaran, menyampaikan materi pelajaran secara tulisan setiap pembelajaran dikelas dan menyampaikan materi pelajaran sudah memberi handout.

b. Aspek Agresive

Aspek agresive menghasilkan jumlah skor sebanyak 613 dan memiliki nilai mean 3.065 yang merupakan nilai mean diantara keempat pernyataan yang diteliti. Nilai tersebut termasuk dalam kategori Baik sesuai dengan rating skor skala penilaian. Dari nilai di atas berarti kegiatan belajar mengajar dikelas, guru menggunakan laptop dalam penyampaian materi pelajaran, ada kesempatan untuk mengcopy materi pelajaran dalam media elektronik, setelah materi usai disampaikan, kegiatan belajar mengajar dikelas dan guru memberi tugas kelompok dikelas untuk diselesaikan secara bersama-sama.

\section{c. Aspek Non Assertive}

Aspek non assertive menghasilkan jumlah skor sebanyak 620 dan memiliki nilai mean 3.100 yang merupakan nilai mean diantara keempat pernyataan yang diteliti. Nilai tersebut termasuk dalam kategori Baik sesuai dengan rating skor skala penilaian. Dari nilai di atas berarti guru menerangkan materi pelajaran mengadakan suatu simulasi atau permainan, guru memberikan pertanyaan, agar siswa mampu menangkap materi yang diberikan, guru bersedia menjelaskan kembali materi yang telah diajarkan dan guru memberikan pertanyaan kepada siswa saat pembelajaran dikelas.

\section{Motivasi Belajar Siswa}

\begin{tabular}{lcrl}
\multicolumn{4}{c}{ Item Statistics } \\
\hline & Mean & $\begin{array}{c}\text { Std. } \\
\text { Deviation }\end{array}$ & $\mathrm{N}$ \\
\hline ITEM 1 & 3.18 & .523 & 50 \\
ITEM 2 & 3.22 & .616 & 50 \\
ITEM 3 & 3.14 & .639 & 50 \\
ITEM 4 & 3.20 & .639 & 50 \\
ITEM 5 & 3.22 & .616 & 50 \\
ITEM 6 & 3.40 & .700 & 50 \\
ITEM 7 & 3.08 & .804 & 50 \\
ITEM 8 & 3.18 & .720 & 50 \\
ITEM 9 & 3.20 & .700 & 50 \\
ITEM 10 & 3.14 & .756 & 50 \\
ITEM 11 & 2.96 & .807 & 50 \\
ITEM 12 & 3.42 & .702 & 50 \\
ITEM 13 & 3.08 & .665 & 50 \\
ITEM 14 & 3.12 & .627 & 50 \\
\hline
\end{tabular}

Sumber: Hasil pengolahan data pada lampiran

\section{a. Aspek Pleasure (Kesenangan)}

Aspek pleasure (kesenangan) menghasilkan jumlah skor sebanyak 477 dan memiliki nilai mean 3.18 yang merupakan nilai mean diantara ketiga pernyataan yang diteliti. Nilai tersebut termasuk dalam kategori Tinggi sesuai dengan rating skor skala penilaian. Dari nilai di atas berarti bahwa siswa berusaha mengerjakan soal-soal latihan mata pelajaran di rumah, siswa merasa senang terhadap materi pelajaran yang diberikan oleh guru 
dan siswa melengkapi buku referensi dengan meminjam buku di perpustakaan.

b. Aspek Relevance (Hubungan)

Aspek relevance (hubungan) menghasilkan jumlah skor sebanyak 491 dan memiliki nilai mean 3.27 yang merupakan nilai mean diantara ketiga pernyataan yang diteliti. Nilai tersebut termasuk dalam kategori Tinggi sesuai dengan rating skor skala penilaian. Dari nilai di atas berarti bahwa siswa berusaha menyalin catatan teman dengan meminta penjelasan apabila terpaksa tidak mengikuti pelajaran, siswa berusaha mengerjakan tugas sendiri semaksimal mungkin dan siswa meningkatkan prestasi belajar dengan menambah jam belajar dirumah.

\section{c. Aspek Confidence (Percaya Diri)}

Aspek confidence (percaya diri) menghasilkan jumlah skor sebanyak 630 dan memiliki nilai mean 3.15 yang merupakan nilai mean diantara keempat pernyataan yang diteliti. Nilai tersebut termasuk dalam kategori Tinggi sesuai dengan rating skor skala penilaian. Dari nilai di atas berarti bahwa siswa dalam menghadapi ulangan harian mempelajari materi 3 hari sebelum ulangan, siswa mencari mencari sumber belajar dan belajar kelompok untuk lebih memahami materi pelajaran, siswa mengajak teman untuk belajar bersama membahas latihanlatihan soal mata pelajaran dan siswa tetap belajar dengan sungguh-sungguh untuk mempertahankan nilai yang anda peroleh.

\section{d. Aspek Effort (Upaya)}

Aspek effort (upaya) menghasilkan jumlah skor sebanyak 629 dan memiliki nilai mean 3.15 yang merupakan nilai mean diantara keempat pernyataan yang diteliti. Nilai tersebut termasuk dalam kategori Tinggi sesuai dengan rating skor skala penilaian. Dari nilai di atas berarti bahwa siswaselalu berusaha lebih giat belajar agar berprestasi di sekolah, siswa mengerjakan soal-soal latihan saat jam pelajaran tersebut kosong, siswa tidak pernah meminta jawaban dari teman pada saat ulangan harian dan siswa memiliki target nilai ulangan harian yang tinggi dalam setiap mata pelajaran.

Pengujian hipotesis dalam penelitian ini dengan tujuan mengetahui pengaruh gaya komunikasi guru terhadap motivasi belajar siswa kelas VIII SMPN 3 Wonogiri.Teknik analisis data dalam penelitian ini yaitu Regresi Linier Sederhana diolah menggunakan SPSS 17.0. Berdasarkan tabel 11 diperoleh persamaan regresi linier sederhana sebagai berikut: $Y=27,617+0,463 X$. Persamaan tersebut memperlihatkan bahwa koefisien regresi dari variabel independen bernilai positif, artinya variabel gaya komunikasi guru berpengaruh signifikan terhadap motivasi belajar siswa.

Tabel 11. Rangkuman Hasil Uji Regresi Linier Berganda

\begin{tabular}{llll} 
Variabel & Koefisien Regresi & $t$ & Sig \\
Konstanta & 27,617 & 6,994 & 0,000 \\
Gaya komunikasi & 0,463 & 4,343 & 0,000 \\
$F_{\text {hitung }}=18,862$ & & & \\
$R^{2}=0,282$ & & & \\
Sumber: Hasil pengolahan data pada lampiran & \\
\hline
\end{tabular}

Adapun hasil pengujian hipotesis dalam penelitian ini yaitu dalam uji t, nilai t sebesar 4,343 dengan nilai probabilitas (sig) 0,000. Karena nilai sig $<0,05$ maka keputusannya $\mathrm{H}_{0}$ ditolak dan $\mathrm{H}_{1}$ diterima, yang berarti bahwa terdapat pengaruh gaya komunikasi guru (X) terhadap motivasi belajar siswa (Y). Uji F, nilai F sebesar 18,862 dengan nilai probabilitas (sig) 0,000. Karena nilai sig $<0,05$ maka keputusannya $\mathrm{H}_{0}$ ditolak dan $\mathrm{H}_{1}$ diterima, yang berarti bahwa terdapat pengaruh secara bersama-sama gaya komunikasi guru $(\mathrm{X})$ terhadap motivasi belajar siswa $(\mathrm{Y})$. Uji Koefisien Determinasi diperoleh nilai $\mathrm{R}_{\text {square }}$ sebesar 0.282. Hal ini mengungkapkan bahwa besarnya koefisien determinan (pengaruh) $X$ terhadap $Y$ sebesar 0.282 . Artinya bahwa $28,2 \%$ variabel motivasi belajar siswa $(Y)$ dapat dijelaskan oleh variabel gaya komunikasi guru $(\mathrm{X})$, sedangkan sisanya $71,8 \%$ dijelaskan oleh variabel lain di luar model.

Meskipun dalam penelitian ini pengaruh gaya komunikasi guru terhadap motivasi belajar siswa kurang maksimal, akan tetapi hasil penelitian ini didukung penelitian Sandri Agnesia (2009) yang mengatakan bahwa didalam proses interaksi antara siswa dan guru membutuhkan komponen-komponen pendukung yang tidak dapat dilepaskan dari 
segi normatif, inilah yang mendasari proses belajar mengajar.

Dalam penelitian ini menunjukkan bahwa gaya komunikasi guru bukan merupakan faktor yang mendominasi terciptanya atau meningkatnya motivasi siswa. Hal ini terjadi karena terdapat beberapa faktor lain yang mempengaruhinya, antara lain: faktor dari dalam dan faktor dali luar. Faktor dari dalam (intern) dapat dikelompokkan menjadi tiga aspek yaitu aspek yang bersifat kognitif (rendahnya kapasitas intelektual), aspek bersifat afektif yaitu labilnya emosi dan sikap seseorang, dan aspek psikomotor( kecenderungan seseorang untuk bertindak sesuatu). Sedangkan faktor dari luar selain gaya komunikasi guru yaitu lingkungan keluarga dan lingkungan masyarakat. Lingkungan keluarga dijelaskan dengan bagaimana sikap orang tua ataupun keluarga dalam menghadapi atau menanggapi anak (Agnesia, 2009).

\section{Pembahasan Hasil Analisis Data}

Dari analisis data, penelitian ini menyimpulkan bahwa gaya komunikasi guru berpengaruh pada motivasi belajar siswa. Seperti yang dikatakan oleh Heimlich dan Norland, 2002 bahwa mengajar dan gaya belajar adalah perilaku atau tindakan yang guru dan peserta didik tunjukkan pada saat pembelajaran. Pengajaran perilaku mencerminkan keyakinan dan nilai-nilai guru dalam mentranser ilmu pengetahuan. Perilaku peserta didik memberikan wawasan ke dalam cara memandang peserta didik, berinteraksi, dan merespon terhadap lingkungan di mana pembelajaran terjadi (Ladd dan Ruby, 1999). Dalam faktanya, banyak siswa mengalami kebingungan dalam menerima pelajaran karena tidak mampu mencerna materi yang diberikan oleh guru. Ternyata, banyaknya kegagalan siswa mencerna informasi dari gurunya disebabkan oleh ketidaksesuaian gaya komunikasinya. Sebaliknya, apabila gaya komunikasi guru sesuai dengan gaya belajar siswa, semua pelajaran (termasuk pelajaran matematika) akan terasa sangat mudah dan menyenangkan. Guru juga senang karena punya siswa yang semuanya cerdas dan berpotensi untuk sukses pada jenis kecerdasan yang dimilikinya. Pada penelitian ini menunjukkan bahwa gaya komunikasi non assertive yang paling tinggi pengaruhnya terhadap motivasi belajar siswa, siswa merasa lebih termotivasi, lebih nyaman dan senang apabila seorang guru menggunakan gaya komunikasi non assertive, berbeda dengan penelitian yang dilakukan Urea, 2013. Dalam penelitian urea gaya komunikasi assertive lebih besar pengaruhnya dari pada gaya komunikasi yang lain, dengan adanya disiplin guru membuat siswa lebih termotivasi dan mendekatkan hubungan guru dengan siswa.

Dalam proses belajar mengajar di kelas penting adanya rasa senang dibenak siswa. Hal tersebut dimakhsudkan supaya siswa merasa nyaman dan semangat mengikuti proses belajar mengajar. Terdapat hal positif yang disebabkan oleh perilaku guru di SMPN 3 Wonogiri, diantaranya yaitu kesenangan yang diciptakan guru, membuat siswa merasa senang akan mata pelajaran yang diberikan. Sesuatu yang positif tersebut dapat meningkatkan motivasi belajar siswa maupun meningkatkan semangat belajar siswa. Pernyataan diatas sejalan dengan Brekelmans (dalam Brok, 2005) yang menyatakan bahwa penelitian lain menemukan hubungan positif antara keramahan dan pemahaman perilaku, kesenangan, keyakinan, percaya diri, yang berkaitan dengan sejumlah mata pelajaran, sedangkan hubungan negatifyang ditemukan dengan menegur, tidak puas, dan kekerasan.

Didalam proses belajar mengajar terdapat hubungan antara siswa dengan guru. Hubunganyang baik antara guru dan siswa mendorong terciptanya pembelajaran yang maksimal. Dari wawancara yang dilakukan peneliti dengan siswa di SMPN 3 Wonogiri didapatkan hasil bahwa siswa merasa lebih termotivasi oleh guru yang perhatian, sabar, menyenangkan dan dekat dengan siswa.Sejalan dengan hasil tersebut, Prapanca (2012) mengatakan bahwakegiatan belajar mengajar didalam suatu sekolah dapat dipengaruhi oleh beberapa faktor, salah satunya yaitu dipengaruhi hubungan yang terjalin antara siswa dengan guru. Jadi dapat dikatakan cara belajar seorang siswa juga dapat dipengaruhi oleh hubungannya 
dengan guru siswa tersebut. Dalam suatu hubungan (relasi) yang terjalin dengan baik, secara tidak langsung akan menimbulkan rasa suka siswa terhadap guru kemudian akan menjalar kepada rasa suka akan mata pelajaran yang diajarkan, sehingga seorang siswa akan bersemangat dan berusaha sungguh-sungguh mempelajari mata pelajaran tersebut. Begitu juga sebaliknya apabila siswa tidak suka dengan guru, akan terjadi hubungan yang tidak baik dan siswa malas untuk mempelajari mata pelajaran guru tersebut. Hal tersebut berakibat pada hasil siswa nantinya, Brekelmans, dkk (dalam Brok 2005) menjelaskan bahwa ada beberapa alasan untuk memperhatikan perilaku antarpribadi guru. Pertama, perilaku tersebut adalah komponen utama di dalam kelas dan banyak guru yang berpengalaman di dalam kelas. Kedua, penelitian telah menunjukkan bahwa perilaku antarpribadi guru adalah hal yang terkait dengan prestasi siswa dan motivasi dalam semua subjek.

Percaya diri merupakan percaya akan kemampuan yang dimiliki. Kepercayaan diri sangat penting didalam segala bidang, termasuk bidang akademik. Menurut Martini (dalam Santoso, 2015)kepercayaan diri merupakan suatu keyakinan yang dimiliki seseorang agar dapat berperilaku sesuai dengan apa yang diinginkan. Dari penelitian ini didapatkan hasil bahwa siswa di SMPN 3 Wonogiri merasa lebih percaya diri apabila diajar oleh guru yang selalu memotivasi siswa dan memberi semangat siswa sehingga mereka (siswa) merasa nyaman dan mendapatkan prestasi yang diinginkan. $\mathrm{Hal}$ ini sejalan dengan Taylor (dalamSafitri, 2015)yang mengatakan bahwa kepercayaan diri adalah keyakinan seseorang akan suatu kemampuan yang dimiliki untuk mencapai target tertentu.

Dalam penelitian ini ditemukan hasil bahwa semangat serta motivasi belajar yang diberikan guru ternyata dapat menjadikan siswa selalu berupaya atau berusaha meraih prestasi.Hasil penelitian itu diperkuat dengan pernyataan Mc. Donald yang dikutip Hamalik (dalam Al-Haddad, 2014) mendefinisikan motivasi merupakan perubahan energi dalam diri individu yang ditandai akan timbulnya perasaan dan reaksi guna mencapai sebuah tujuan. Ketika kita belajar mengenai motivasi belajar, motivasi belajar tersebut dapat meningkatkan semangat siswa dalam menuntut ilmu.

\section{E. PENUTUP}

Penelitian ini menunjukkan bahwa gaya komunikasi guru berpengaruh signifikan terhadap motivasi belajar siswa kelas VIII SMP Negeri 3 Wonogiri. Hal ini disebabkan dalam proses belajar mengajar tidak akan terlepas dengan interaksi. Agar tujuan belajar tercapai maka dalam interaksi tersebut harus didukung dengan komunikasi yang efektif. Pendidik dapat menggunakan komunikasi dalam beberapa bentuk meliputi: penyampaian informasi lisan,penyampaian informasi secara terulis, komunikasi melalui media elektronika dan komunikasi dalam aktivitas kelompok. Dengan adanya penerapan gaya komunikasi guru yang menyenangkan, secara tidak langsung hal ini dapat juga menumbuhkan semangat atau motivasi belajar siswa terhadap suatu mata pelajaran. Motivasi belajar yang timbul dalam diri siswa disebabkan karena adanya cita-cita atau dorongan untuk memperoleh hasil yang diharapkan. Pada penelitian ini menunjukkan bahwa gaya komunikasi non assertive yang paling tinggi pengaruhnya terhadap motivasi belajar siswa, siswa merasa lebih termotivasi, lebih nyaman dan senang apabila seorang guru menggunakan gaya komunikasi non assertive, berbeda dengan penelitian yang dilakukan Urea, 2013. Dalam penelitian urea gaya komunikasi assertive lebih besar pengaruhnya dari pada gaya komunikasi yang lain, dengan adanya disiplin guru membuat siswa lebih termotivasi dan mendekatkan hubungan guru dengan siswa. 


\section{DAFTAR PUSTAKA}

Agnesia, Sandri. 2009. Faktor-Faktor yang Mempengaruhi Motivasi Belajar Siswa Kelas VIII dalam Pelajaran IPS Ekonomi di SMPN\# Pekanbaru. Skripsi. Fakultas Keguruan dan Ilmu Pendidikan Universitas Islam Riau.

Al-Haddad, Muhammad. 2014. Perilaku Guru dalam Mengajar dan Motivasi Belajar Siswa. Skripsi. Fakultas Agama Islam Universitas Muhammadiyah Surakarta.

Bailey, dkk. 2015. The Influence of Motivation and Adaption on Students Subjective Wellbeing, Meaning in life and Academic Performance. Journal of Higher Education Research \& Development.

Brok, P. Den. 2005. The Effect of Teacher Interpersonal Behaviour on Students 'SubjectSpecific Motivation. The Journal of Classroom Interaction.

Fahirin, Miftahul. 2014. Pengaruh Kondisi Mahasiswa dan Lingkungan Belajar terhadap Motivasi Belajar Mahasiswa Program Studi Pendidikan Administrasi Perkantoran Fakultas Ekonomi Universitas Negeri Yogyakarta. Skripsi. Fakultas Ekonomi Universitas Negeri Yogyakarta.

Goh, S. C., \& Khine, M. S. 2002. Studies in Educational Learning Environments: An International Perspective.

Haider, dkk. 2015. A Study of Students Motivation and its Relationship with their Academic Performance. Journal of Resources Development and Management.

Heimlich, J.E., Norland, E. 2002. Teaching style: Where are we now? New Directions for Adult and Continuing Education (93), 17-25. Retrieved January 23, 2004 from ProQuest Database.

Krisyantono, Rachmat. 2010. Teknik Praktis Riset Komunikasi. Jakarta: Prenada Media Group.

Ladd, P and Ruby, Jr R. 2009. Learning style and adjustment issues of international students, Journal of Education for Business, 74, 363-367.

Prapanca, Tomang. 2012. Minat Siswa Kelas IX terhadap Mata Pelajaran Tata Boga di SMA N 1 Temon. Skripsi. Fakultas Teknik Universitas Negeri Yogyakarta.

Putro, Eko dkk. 2012. Pengaruh Kinerja Guru terhadap Motivasi Belajar Siswa. Jurnal. Cakrawala Pendidikan.

Radovan, dkk. 2015. Relations between Students' Motivation, and Perceptions of the Learning Environment. Journal of Ljubljana Faculty of Education.

Rusnandi, Hilma. 2011. Pengaruh Kemampuan Komunikasi Guru dan Motivasi Belajar Siswa terhadap Prestasi Belajar Mata Diklat Melakukan Prosedur Administrasi Siswa Kelas X Program Keahlian Administrasi Perkantoran di SMK Negeri 9 Semarang. Skripsi. Fakultas Ekonomi Universitas Negeri Semarang.

Safitri, Dini. 2015. Hubungan Rasa Percaya Diri dengan Prestasi Belajar Matematika Siswa Kelas V SDN Kramat Jati 19 Pagi. Skripsi. Fakultas Ilmu Tarbiyah dan Keguruan Universitas Islam Negeri.

Sanusi, A. 2012. Metodologi Penelitian Bisnis. Jakarta: Salemba Empat.

Santoso, Ardriyanto. 2015.Hubungan antara Kepercayaan Diri dengan Kompetensi Sosial pada Siswa SMP N 16 Surakarta. Jurnal. Fakultas Psikologi Universitas Muhammadiyah Surakarta.

Susetyo, Yuli Fajar. Perubahan Perilaku Mengajar yang Humanis Guru Sekolah Dasar Setelah 
Menjalani Pelatihan Berfikir Positif. Fakultas Psikologi Universitas Gajah Mada.

Urea, Roxana. 2013. The Impact of Teachers Communication Styles on Pupils Self-Safety throughout the Learning Process. Journal of Social and Behavioral Sciences.

Wesson, C. J. 2005. The communication and influence of confidence and uncertainty,.

Yuliansari, dkk. Peran Dominan Motivasi Intrinsik dan Motivasi Ekstrinsik Siswa Putri dalam Mengikuti Kegiatan Ekstrakulikuler Futsal. Jurnal Pendidikan Olahraga dan Kesehatan. 